\title{
Ice surface velocity patterns on Seward Glacier, Alaska/Yukon, and their implications for regional tectonics in the Saint Elias Mountains
}

\author{
Andrew L. J. FORD, ${ }^{1}$ Righard R. FORSTER, ${ }^{1}$ Ronald L. BRUHN ${ }^{2}$ \\ ${ }^{1}$ Department of Geography and ${ }^{2}$ Department of Geology and Geophysics, University of Utah, Salt Lake City, UT 84112, U.S.A. \\ E-mail: andrew.ford@csbs.utah.edu
}

\begin{abstract}
Seward Glacier, on the Alaskan/Yukon border along the Gulf of Alaska, sits atop an important structural and morphological junction in the Saint Elias orogen. It is situated at the intersection between the Fairweather and Bagley strike--slip faults, and in the hanging wall of the Malaspina and Chugach-Saint Elias thrust faults. An ice surface velocity map of Seward Glacier derived from interferometric synthetic aperture (InSAR) reveals a complex flow pattern, which implies there is a previously unmapped northwesttrending supra-/subsurface ridge crossing the Seward. Analysis of additional remotesensing images, ASTER, ERS SAR and the InSAR coherence map, confirms this observation. The presence of this ridge leads to a set of tectonic models describing the possible interaction of the underlying faults.
\end{abstract}

\section{INTRODUCTION}

The Saint Elias Mountains are extensively glaciated because rapid uplift along the Pacific coast was coupled with global cooling during the late Neogene $\left(10 \times 10^{6}\right.$ years BP) (Plafker, 1987) and present-day climate supplies $>3 \mathrm{~m} \mathrm{a}^{-1}$ w.e. precipitation (Gustavson and Boothroyd, 1987). Glacier-mantled peaks rise to elevations of nearly $6 \mathrm{~km}$, and tower above large alpine ice fields that spill onto the coastal plain to form two of the world's largest piedmont glaciers, the Malaspina and Bering. There is a remarkable spatial correspondence between a number of glaciers and major structural boundaries within the orogen; this observation raises significant questions concerning how glacial and tectonic processes interact to create and modify the landscape during mountain building (e.g. Meigs and Sauber, 2000; Merrand and Hallet, 2000; Jaeger and others, 2001). In several areas important tectonic features lie buried beneath the glacial ice.

Seward Glacier is a prime example of this, situated within the regional transition from mostly strike-slip to oblique thrust faulting. Specifically, the Seward basin is located at the junction between the Fairweather transform fault and the Bagley splay of the Contact fault system, a series of poorly exposed strike--slip faults that extend westward from the central part of the Seward Glacier basin into the trough of the Bagley Ice Valley (Fig. 1). The Contact fault system is a regional strike-slip plate boundary that formed during the Early Cenozoic $\left(50-30 \times 10^{6}\right.$ years BP) (Plafker and others, 1994), and was probably reactivated during collision of the Yakutat Terrane in the last $20 \times 10^{6}$ years (Savage and Lisowski, 1986). Geodetic measurements, seismicity and Quaternary geology all provide evidence of ongoing deformation (Plafker and others, 1994; Sauber and others, 1997; Fletcher and Freymueller, 1999). Notable earthquakes include the Yakutat Bay earthquakes of 1899 (Tarr and Martin, 1912) which culminated in two $\mathrm{M}>8$ thrust-events (personal communication from G. Plafker and W. Thatcher, 1982), the M 7.1 Saint Elias earthquake in 1979 (Estabrook and others, 1992) and the M 8.3 earthquake on the Fairweather transform fault in 1958 (Page, 1969). While elevation of the Seward Glacier basin and surrounding mountain peaks is primarily the result of uplift caused by thrusting of the Yakutat Terrane beneath the southern edge of Alaska, the topography and structure of the basin are probably also controlled by erosion and deformation at the junction between the Fairweather fault and Contact fault system (i.e. Seward and Bagley fault strands).

Seward Glacier fills a broad basin, approximately $70 \mathrm{~km}$ east-west and $25 \mathrm{~km}$ north-south, exiting south through a narrow throat ( $\sim 5 \mathrm{~km}$ in width) and cascading into the head of Malaspina Glacier (Fig. 1). The Malaspina is a temperate glacier near the pressure-melting point of ice (Gustavson and Boothroyd, 1987), with three distinct lobes. The smaller outer lobes are fed by Agassiz and Marvine Glaciers, whereas Seward Glacier sources the larger inner lobe. Seward Glacier is fed from the west by the eastern portion of the Bagley Ice Valley (Columbia Glacier) and from several cirques and hanging glaciers on the north and south sides of the Bagley Ice Valley. The Valerie and other unnamed glaciers flowing west from the Mount Foresta-Mount Vancouver range (Fig. 1) also feed the Seward. Whereas there have been glaciological investigations of the Malaspina (e.g. Allen and Smith, 1953; Sharp, 1958; Gustavson and Boothroyd, 1987; Molnia and Jones, 1989), there is a paucity of data for Seward Glacier. As part of a regional crustal deformation study, Sauber and others (2000) report ice surface lowering of 120-137 m estimated to have occurred since 1900 from trimlines and erratic boulders on ridge tops from two nunataks near Seward Glacier. Fatland and Lingle (1998) used interferometric synthetic aperture (InSAR) to derive radar line-of-sight velocity measurements in the Bagley Ice Valley west of the divide that sources Bering Glacier. 


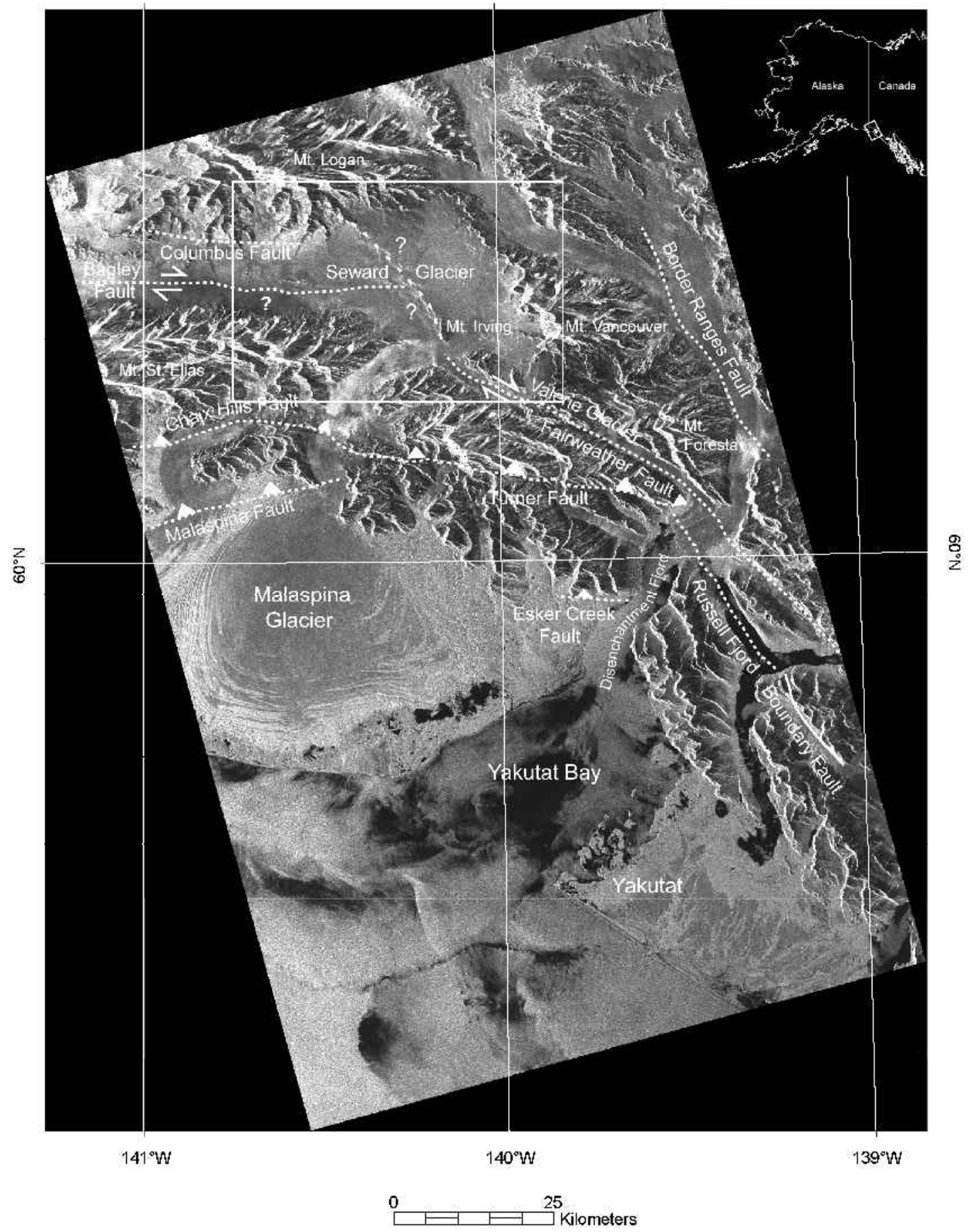

Fig. 1. ERS-1 ascending amplitude image showing the context of this study, annotated with faults and place names. White box indicates the extent of subsequent figures.

The goal of our study was to use ice surface velocity patterns derived from InSAR along with optical and SAR remote-sensing images of the surface of Seward Glacier and its environs to identify features that might reveal the nature of the tectonics hidden beneath the ice.

\section{DATA SOURGES}

\section{DEM}

A digital elevation model (DEM) was used for topographic analysis and in the derivation of the InSAR velocity map. We mosaicked two U.S. Geological Survey (USGS) 15 min DEM tiles of the area (Mount Saint Elias West and Mount Saint
Elias Central). These tiles are analogous to the 1:250 000 scale topographic map series from the USGS based on 1959 aerial photography and updated in 1983 . The DEM was artificially shaded from the southwest with a sun elevation of $45^{\circ}$ so as to reveal subtle topography (Fig. 2).

\section{InSAR}

We used an ascending European Remote-sensing Satellite (ERS) SAR amplitude scene of upper Seward Glacier for visual interpretation, in addition to an ice surface velocity map derived from repeat-pass interferometry (Goldstein and others, 1993; Kwok and Fahnestock, 1996) (Fig. 3). In order to compute the three-dimensional ice velocity (rather than only the radar line-of-sight velocity) both ascending and descend- 

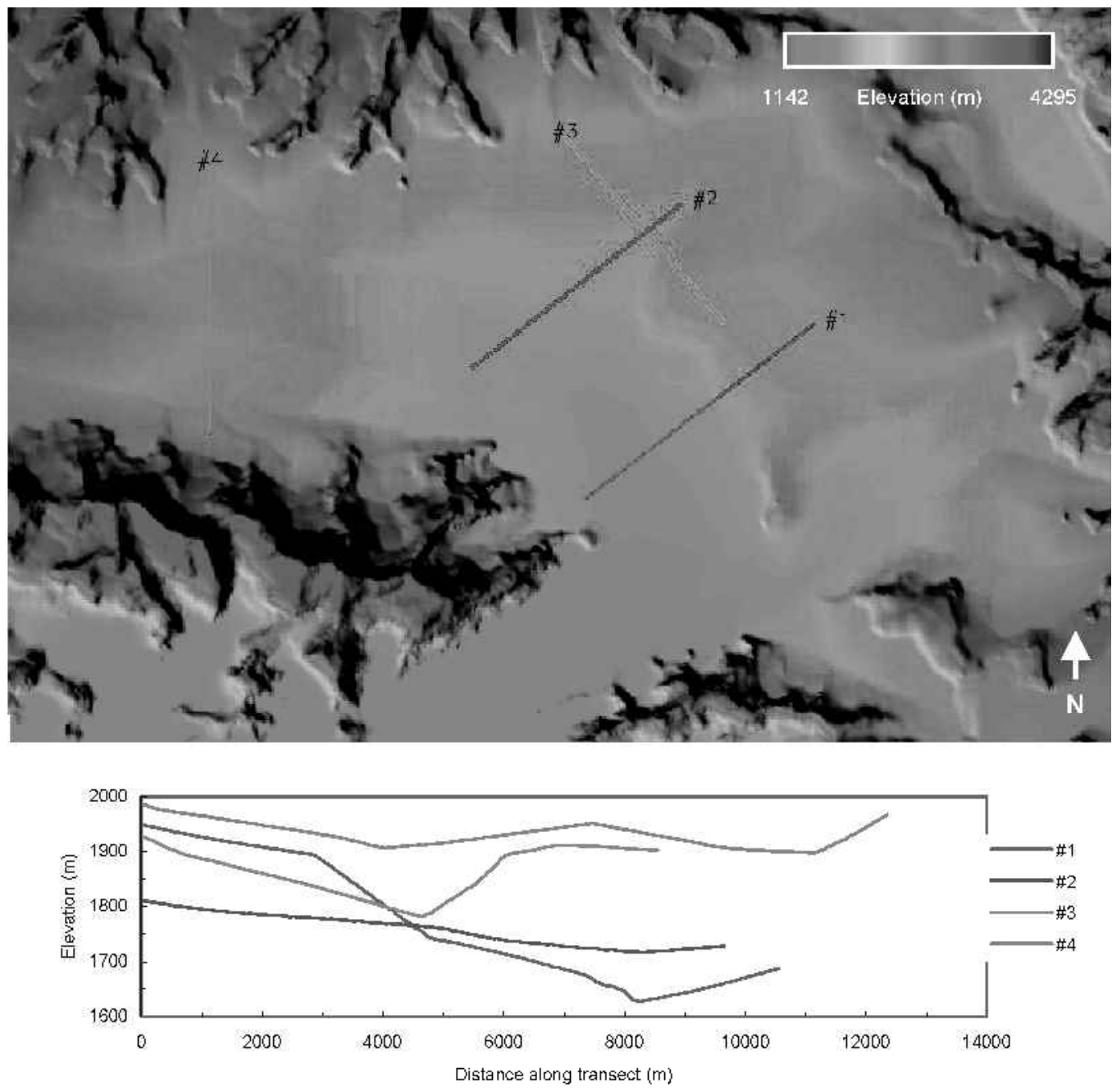

Fig. 2. Hill-shaded USGS 1:250 000 (15 min) DEM mosaic, with height as colour. Labels indicate start of transects.

ing ERS-1 and -2 scenes from the tandem-mission phase (24 $\mathrm{h}$ temporal baselines) with short perpendicular spatial baselines $\left(B_{\text {perp }} \sim 80 \mathrm{~m}\right)$ were processed. Care was also taken in using ascending and descending pairs acquired just 4 days apart to minimize temporal variations in the two measured velocity fields (Table 1). The horizontal ice surface velocity was calculated by combining both ascending and descending displacements (using the two-pass method) together with topographic slope (as derived from the mosaicked 15 min USGS DEMs described above) and assuming surface-parallel flow (Joughin and others, 1998). One of the two resulting interferometric coherence maps was also utilized to highlight areas of temporal decorrelation, rotation and steep slopes (Zebker and others, 1996; Fig. 4).

\section{ASTER}

To visually examine the area, we used two mosaicked Advanced Spaceborne Thermal Emission and Reflection Radiometer (ASTER) scenes (Fig. 5) from NASA's TERRA satellite. These scenes were acquired on 6 November 2001, so as to take advantage of the shadow cast from the seasonal low sun angle, which accentuates subtle topographic features on an otherwise smooth ice surface. The sun's elevation at the time of acquisition (20:58 GMT) was $14^{\circ}$, with an azimuth of $179^{\circ}$. This also had the unfortunate effect of casting shadows over some parts of Seward Glacier from the moun- tain range immediately to the south, including Mount Saint Elias. However, detail could still be discerned within this shadow with appropriate contrast stretching. Thin cloud over lower Seward and Malaspina Glaciers also created some subtle shadow, although we were able to penetrate much of the cloud itself using ASTER's 0.76-0.86 $\mu$ m nearinfrared (NIR) band 3N. Band 3N was also chosen for its $15 \mathrm{~m}$ spatial resolution, whilst the visible bands (1 and 2) of the same resolution were saturated by the high reflectivity of the snow and ice surface. The data were low-pass filtered to remove high-frequency striping noise.

\section{OBSERVATIONS}

In general, the surface velocity map (Fig. 3) shows the velocity of the western portion of the Seward is higher than that of the eastern portion. Within the western branch there is an area of relatively fast ice $\left(50-90 \mathrm{~m} \mathrm{a}^{-1}\right)$ flowing from west to east along the southern side of the Seward, with slower ice $\left(10-50 \mathrm{~m} \mathrm{a}^{-1}\right)$ on the northern portion of the Seward flowing to the southeast.

The flow from the western portion of the Seward converges and is focused by an apparent northwest-trending structure to the south just north of the narrow throat leading to Malaspina Glacier. Here, the velocity increases to $>100 \mathrm{~m} \mathrm{a}^{-1}$ (Fig. 3, inset A) at the edge of recorded velocities where coherence is lost (Fig. 4, inset A), probably due to the 


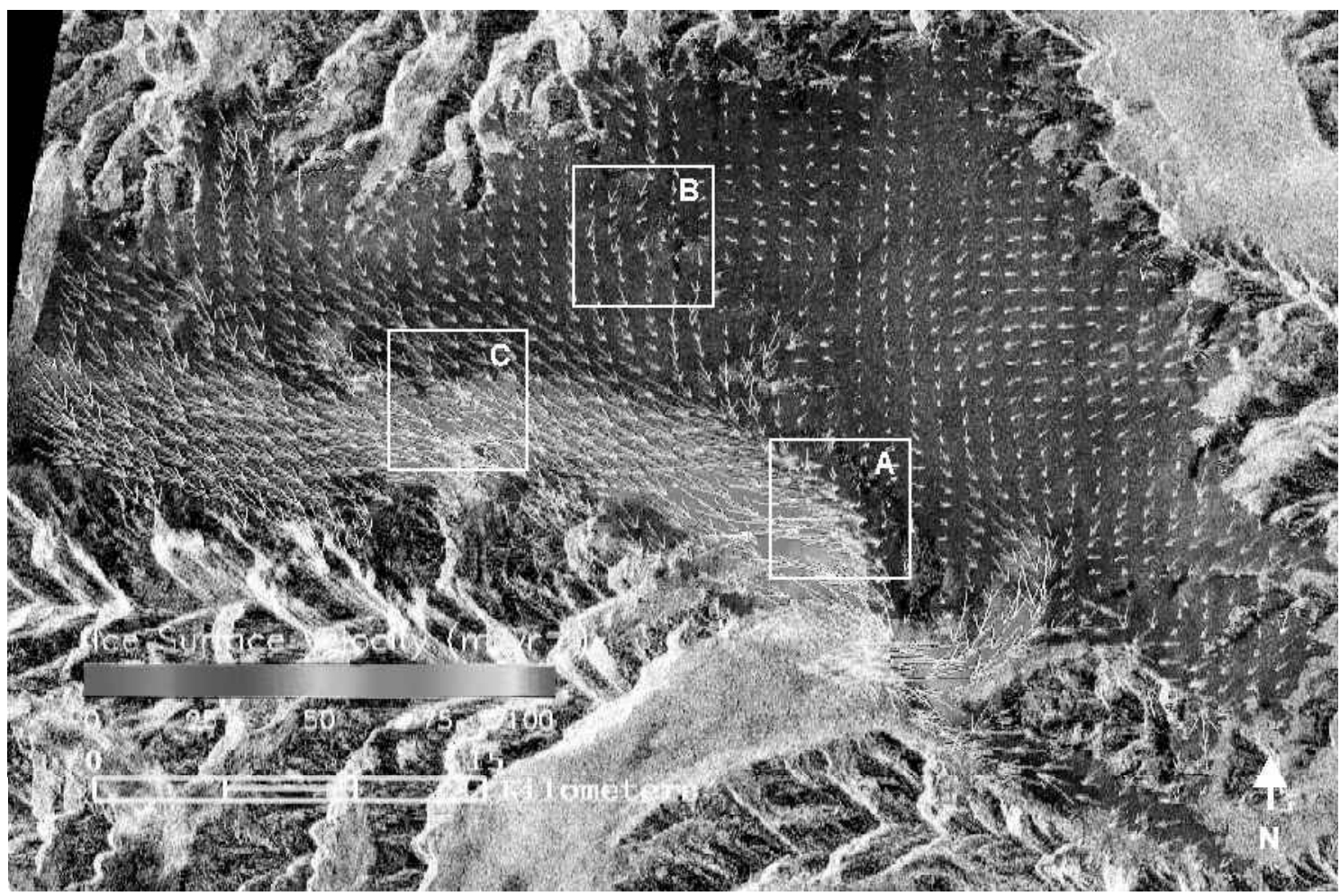

Fig. 3. Velocity map derived from ascending and descending ERS tandem pairs acquired between 21 and 25 October 1995 ( see Table 1). Background image is descending ERS-1 amplitude. Labeled insets refer to observations described in text.

intense crevassing and rotation of seracs (Rignot and others, 1996) as also seen in the ASTER imagery (Fig. 5, inset A).

The DEM confirms the presence of a northwest-trending ridge at the location of the focused flow from the west. Transect 1 (Fig. 2) shows the ridge sloping to the southwest and dropping $150 \mathrm{~m}$ over $1 \mathrm{~km}$. Approximately halfway across the Seward the ridge turns abruptly to the northeast, as shown by the low gradient in transect $2(500 \mathrm{~m}$ over $6 \mathrm{~km})$ (Fig. 2). The slope across this segment (transect 3, Fig. 2) remains high $(100 \mathrm{~m}$ over $500 \mathrm{~m})$. However, since the DEM is based on older topographic contours and aerial photography, its surface may not represent the ice surface at the time of the SAR acquisitions (Table 1). Furthermore, there is the possibility of DEM artifacts due to photogrammetric mapping over sparsely featured, low-contrast terrain.

Our ASTER imagery revealed nunataks coincident with the northwest-trending ridge (Fig. 5, inset B). Mount Irving was known to have several other large neighboring nunataks between itself and Valerie Glacier to the southeast, but ASTER also revealed smaller nunataks breaking the ice surface in a broadly northwesterly direction toward Mount Logan. Associated with these were a series of crevasses cas-

Table 1. ERS SAR scenes used for interferometric processing cading perpendicular to the trend of the nunataks, as shown in Figure 5, inset B. These features imply an elevated basin of ice in the northeastern portion of the Seward flowing into a lower-lying area to the southwest, separated by a northwest-trending ridge at and/or just below the surface. The areas of intense crevassing crossing this ridge coincide with the corridors of increased velocity $\left(30 \mathrm{~m} \mathrm{a}^{-1}\right.$; Fig. 3, inset B).

A region of high returns in the SAR amplitude was also coincident with the ridge, but the linear feature can be traced continuously across the Seward, which is not the case in the ASTER imagery. Many of these high returns might be attributed to crevassing previously identified by ASTER along the northern half of the ridge. However, visual comparison between the SAR amplitude and ASTER scenes in other areas (particularly in close proximity to the north valley sides where rocky spurs plunge below the ice surface) revealed that in many cases the C-band radar was imaging features below dry snow and firn surfaces (Ulaby and others, 1982). This could also be the case with the ridge of nunataks, where steep slopes facing the sensor may be causing high returns. Although we cannot distinguish between high returns from crevassing and high returns from steep subsurface slopes, the presence of either lends additional weight to the notion of a northwest-trending ridge extending across the Seward, in contrast to the DEM (Fig. 2).

Both descending and ascending interferometric pairs revealed relatively high coherence $(0.6-0.9)$ over much of Seward Glacier, right up to the throat that feeds Malaspina Glacier. However, there are several locations where the coherence drops abruptly. A striking decrease is observed along narrow segments where the northwest-trending ridge divides Seward Glacier (Fig. 4, insets A and B). As with high-amplitude returns, the drop in coherence could equally be caused where focused extensional crevassing occurs (due to high displacement causing an excessive fringe 


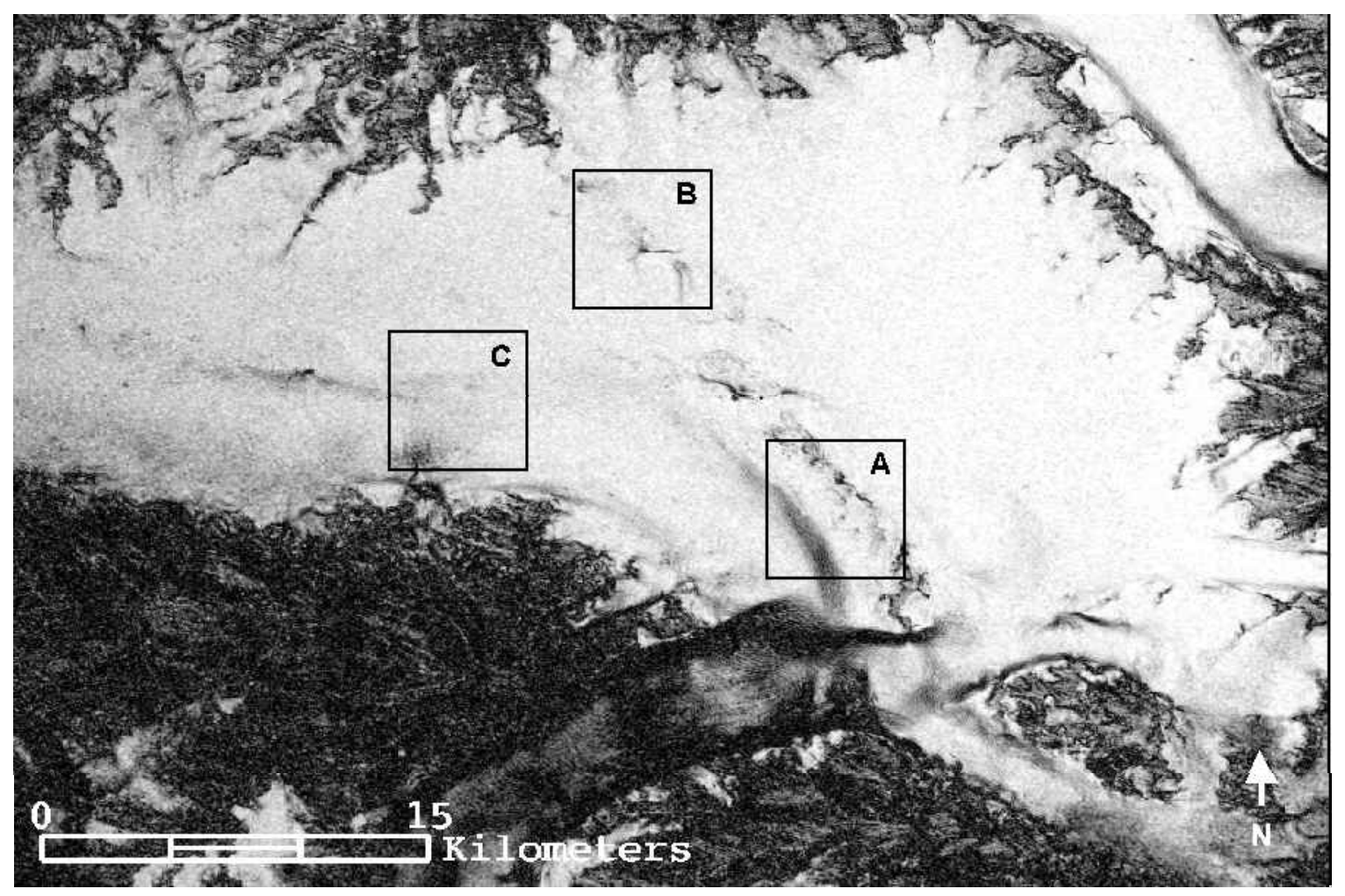

Fig. 4. Descending ERS tandem-pair coherence over Seward Glacier. Labeled insets refer to observations described in text.

rate that breaks up into noise, and/or rotation of ice blocks causing the reorientation of scatterers) or by steep sub- and supraglacial slopes (where the fringe rate is also excessive). A wider but less extensive area of low coherence parallels the northwest ridge where the ice from the west turns toward the south and accelerates (Fig. 4, inset A). The loss of coherence here is probably the result of surface rotation $>1^{\circ}$
(Rignot and others, 1996), a direct consequence of the ridge redirecting the flow.

In the eastern portion of the Seward, the ice-flow direction is more locally variable, with arcuate patterns that converge and are redirected to the west at the Seward throat where the velocity increases to $>100 \mathrm{~m} \mathrm{a}^{-1}$ and coherence is again lost. This channel of fast flow enters the Seward throat

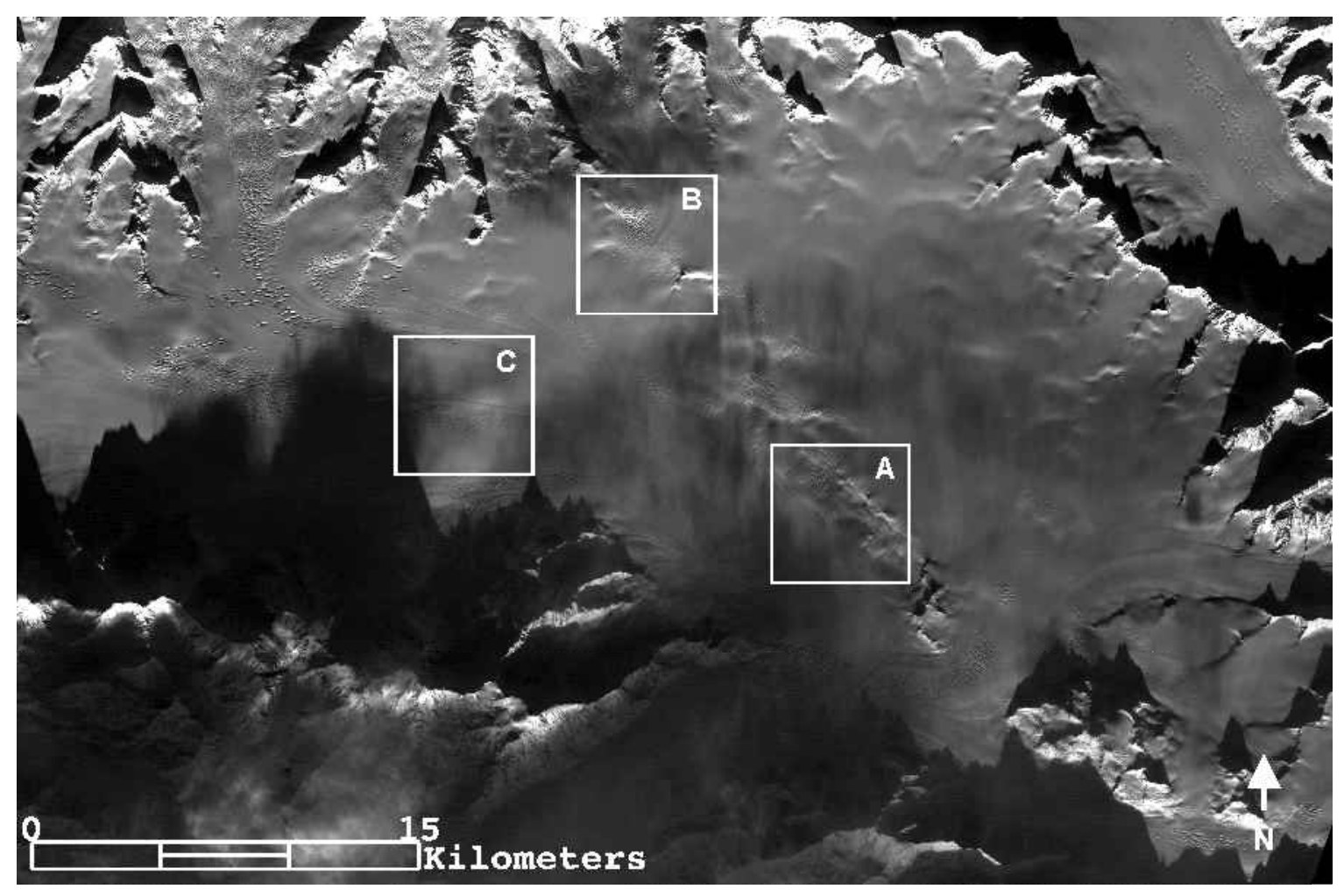

Fig. 5. ASTER band 3N ( NIR) image of Seward Glacier. Labeled insets refer to observations described in text. 

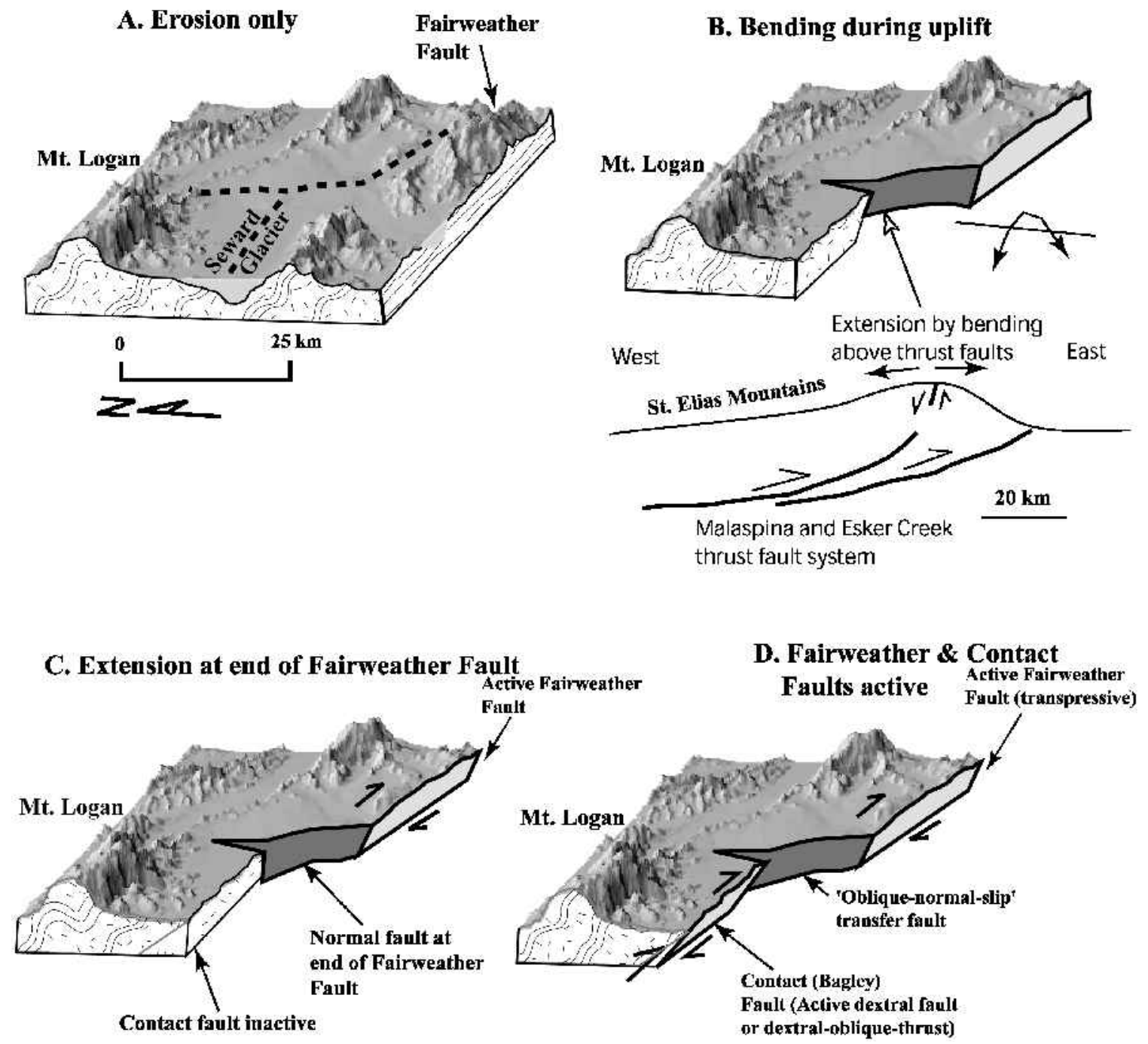

Fig. 6. Sketch diagrams of proposed tectonic models.

immediately south of the northwest-trending linear feature. This slow-flowing half of the Seward does appear to be a plateau of ice trapped within a basin formed by a supra- and subglacial ridge.

There also appears to be a subtle feature in the western portion of the Seward, separating fast and slow ice velocities (Fig. 3, inset G). This feature trends approximately west to east, effectively dividing the valley longitudinally in half, as observed in the SAR amplitude data (Fig. 1). We also noted coincident crevassing in our ASTER image (Fig. 5, inset $\mathrm{G}$ ) and a decrease in coherence (Fig. 4, inset C), both of which are characteristic of a lateral shear margin.

Since this shear margin coincides with the projection of the Bagley splay, it might be reasoned that its location is influenced by subglacial tectonics, but it is far more likely to be dictated by simple glacial dynamics. For instance, the steep sides on the southern wall of the basin contrast with the gently sloping sides of its northern wall (Fig. 2). This indicates the basin is likely to deepen significantly on its southern side, with ice flowing down from the north (as evidenced by the confluence with a large glacier in the velocity map; Fig. 3). With the ice gathering at the deepest point, it is necessary for it to flow rapidly eastward in order to remain close to equilibrium. Therefore, we will primarily use the presence and orientation of the northwest-trending ridge to constrain potential tectonic models of the area.

\section{DISGUSSION: TEGTONIC MODELS OF SUB-ICE STRUGTURE}

The evidence of a near-surface northwest-trending ridge crossing Seward Glacier, from ice surface velocity and remotesensing images, prompts the question, what is the origin of this structure and how might it constrain the set of plausible tectonic models for the intersection of the Fairweather and Bagley faults beneath Seward Glacier? The morphology of the Seward Glacier basin is presumably the product of both glacial erosion and tectonic processes. Here, we speculate on the structure of the basin by proposing and discussing alternative tectonic models that are compatible with our remotely sensed observations. The plausibility of each model is then evaluated by considering geological and geophysical evidence that supplements the remote-sensing observations.

\section{Model A:}

In this model the Fairweather and Contact fault systems are assumed to be inactive and passively uplifted by subjacent thrust faulting beneath the Saint Elias Mountains. The topography of the Seward Glacier basin results solely from preferential erosion of old and inactive faults, tracts of less resistant rock, and from spatial variations in ice mass flux and basal sliding velocity (e.g. MacGregor and others, 2000; Fig. 6a). Erosion of fractured rock along the Fairweather and 
Contact fault systems, together with preferential erosion of east-trending tracts of metamorphic rocks, are the most plausible mechanisms for the development of the east-west-trending valleys occupied by Columbus (Bagley Ice Valley), Seward and Valerie Glaciers.

These processes are probably not alone responsible, however, for the origin of the northwest-trending supra-/ subglacial ridge at the eastern end of the Seward Glacier basin. Structural and metamorphic features trend roughly east-west at regional scale throughout the core of the Saint Elias Mountains (Dusel-Bacon and others, 1994), imparting a strong topographic grain where glaciers preferentially erode faults and weak rocks (e.g. Meigs and Sauber, 2000). Variations in rock strength may be an important factor in the origin of the western Seward Glacier basin where amphibolite-facies metamorphic rocks on the northern flank and part of the southern flank of the basin abut the lower-grade and weaker greenschist-facies rock that floors the basin. The susceptibility of the greenschist-facies rock to erosion is presumably also enhanced because of extensive fracturing along the Contact and Fairweather fault systems.

The origin of the northwest-trending supra-/subglacial ridge in the eastern part of the Seward Glacier basin must be somewhat different than that of the main east-trending part of the basin. The ridge trends at high angle to the Fairweather and Contact faults; it cannot reflect preferential erosion of fractured rock along those faults. Furthermore, the greenschist metamorphic rocks that floor the western part of the basin extend eastward across the ridge into the region surrounding Valerie Glacier. Preferential erosion along the margin of an igneous pluton could create a bedrock ridge that trends at high angle to regional structures, but there are no plutonic rocks exposed in the nunataks along the length of the ridge. These observations lead us to infer that the northwest-trending ridge reflects young tectonic processes rather than solely erosion.

\section{Model B:}

In this model we speculate that tectonic imbrication and underthrusting of the Yakutat terrain along the Malaspina and Esker Creek faults causes normal faulting in the top of the mountain range because the upper thrust plate is uplifted and flexed above the intersection of the Malaspina and Esker Creek faults at depth. The northwest-trending topographic ridge reflects topography generated by normal faulting in the crest of the range (Fig. 6b), while the morphology of the remainder of the basin is controlled primarily by glacial erosion along the east-trending contact fault system.

\section{Model C:}

This model assumes that the Fairweather fault is active but ends abruptly in the eastern part of the Seward Glacier basin. The Contact fault system is either inactive or slipping at a much slower rate than the Fairweather fault. The northwest-trending topographic ridge that appears to emanate from the end of the Fairweather fault and extend across the breadth of the basin is interpreted as the trace of a down-tothe-west normal fault along the eastern boundary of a "pullapart" basin (Fig. 6c).

\section{Model D}

In this model the Contact and Fairweather faults are both transpressional faults with different relative amounts of dextral strike-slip to reverse fault motion. Dominantly strike- slip motion on the northwestern end of the Fairweather fault is transferred through the fault junction to the west-trending Bagley (Contact fault system) fault where the ratio of reverse to strike-slip motion increases dramatically because of the change in fault strike. Notably, Mount Logan, the highest point in the Saint Elias Mountains, occurs just west of the fault junction in a position where maximum uplift is expected if rocks on the southwest side of the Fairweather fault are jammed into the fault junction and thrust beneath the northern flanks of the Seward Basin. This model predicts obliqueslip faulting (strike-slip plus normal motion) along the northwest-trending topographic ridge that emanates from the Fairweather fault (Fig. 6d).

Although each model is plausible on theoretical grounds, those that invoke tectonic influence on basin structure (models B-D) are preferred over the first model of simple glacial erosion (model A). The apparent steepness and proximity of the northwest-trending ridge to the surface of the ice eliminates the simple glacial erosion scenario (model A) because, without recent tectonic activity, such a structure could not withstand the enormous glacial erosion rates present in the area (Gustavon and Boothroyd, 1987). Furthermore, the Seward Glacier basin is located at a critical tectonic junction in the Saint Elias orogenic belt where there is overwhelming evidence for high rates of deformation and complex structural interactions (e.g. Savage and Lisowski, 1986; Estabrook and others, 1992; Plafker and others, 1994).

Further work will be required to properly evaluate models $\mathrm{B}-\mathrm{D}$, and the final result may in fact be a hybrid of all three. According to Plafker and others (1994), up to $200 \mathrm{~km}$ of dextral displacement is required to explain the offset of the high-grade metamorphic rocks exposed in Mount Saint Elias from their correlative unit on the opposite side of the Fairweather transform fault near the Alsek River. This observation implies that dextral shearing along the Fairweather and Contact fault systems occurred within the Seward Glacier basin during the formation of the Saint Elias Mountains.

We need to determine if the Fairweather and Contact fault systems are active, or have become passive features as the result of uplift along the subjacent Malaspina and Esker Creek fault systems. In each of these models, the course of Seward Glacier is strongly impacted by the development of a northwest-trending fault at the crest of the mountain range. This fault subdivides the basin into two parts with significantly different characteristics of ice flow, and deflects the east-flowing ice channel that originates in the western part of the basin towards the south and west, where it flows through the front of the Saint Elias Mountains and onto the coastal plain to the form the Malaspina piedmont glacier.

\section{CONGLUSIONS}

The flow patterns of an InSAR-derived ice surface velocity map (Fig. 3), combined with the interpretation of both an ASTER (Fig. 5) optical image and SAR amplitude image (Fig. 1), have indicated the presence of a previously unmapped ridge that runs in a northwesterly direction across Seward Glacier. The presence of this ridge is also confirmed in an InSAR coherence image (Fig. 4). The ridge appears as a mix of supra- and subsurface peaks. The presence of this ridge helps constrain the set of feasible tectonic models for the 
intersection of two major fault systems, the Fairweather and Contact faults (Bagley splay).

The morphology of the northwest-trending ridge as depicted in the velocity map and remote-sensing images differs significantly from its representation in the DEM (Fig. 2). It is more likely that the DEM itself is in error (possibly due to artifacts of interpolation from original contour data) or that the ice itself has thinned since the DEM was produced, making it unrepresentative of the present ice surface. In either case, the DEM would induce errors when used to remove topographic phase from the interferograms, and again when used to calculate slope with the surface-parallel flow assumption. In this dataset the relatively short perpendicular baselines $(\sim 80 \mathrm{~m})$ produce a velocity error of $2 \mathrm{~m} \mathrm{a}^{-1}$ for every $10 \mathrm{~m}$ of error in the DEM (Joughin and others, 1996, equations (10) and (21)).

In the future, interferometric analysis would ideally make use of the double-difference method (Kwok and Fahnestock, 1996), using one pair of scenes with a long spatial baseline (where phase is dominated by topography) to subtract phase from another pair with a short spatial baseline (where phase is dominated by displacement). This would remove any errors in velocity resulting from an unrepresentative (old) or erroneous (interpolated from contours) DEM. Another viable alternative might be to use the two-pass technique (the method used in this study) with an interferometric DEM derived from a dual-antenna single-pass system operating at a similar wavelength, such as AIRSAR (inTOPSAR mode), or the Intermap Star-3i system.

Our study has shown how remote-sensing data of glaciers can be used to identify subsurface tectonic features, particularly from their influence on ice flow as revealed in interferometric velocity maps. This can in turn aid interpretation of regional tectonics.

\section{ACKNOWLEDGEMENTS}

This study was supported by NASA grant NAG5-10136. The authors would like to thank I. Joughin and A. Meigs for their useful comments that helped improve the manuscript. We also thank the European Space Agency and the Alaska SAR Facility for providing the ERS SAR data used in this study.

\section{REFERENGES}

Allen, G. R. and G. I. Smith. 1953. Seismic and gravity investigations on the Malaspina Glacier, Alaska. Transactions, American Geophysical Union, 34(5), 755-760.

Dusel-Bacon, C., J. R. Csejtey, H. L. Forster, G. O. Doyle, W. J. Nokleberg and G. Plafker. 1994. Distribution, facies, ages and proposed tectonic associations of regionally metamorphosed rocks in east and south-central Alaska. U.S. Geol. Surv. Prof. Pap. 1497-C.

Estabrook, C. H., J. L. Nábelek and A. L. Lemer-Lam. 1992. Tectonic model of the Pacific-North American plate boundary in the Gulf of Alaska from broadband analysis for the 1979 St. Elias, Alaska, earthquake and its aftershocks. 7. Geophys. Res., 97(B5), 6587-6612.
Fatland, D. R. and C. S. Lingle. 1998. Analysis of the 1993-95 Bering Glacier (Alaska) surge using differential SAR interferometry. f. Glaciol., 44(148), $532-546$.

Fletcher, H. J. and I. T. Freymueller. 1999. New GPS constraints on the motion of the Yakutat Block. Geophys. Res. Lett., 26(19), 3029-3032

Goldstein, R. M., H. Engelhardt, B. Kamb and R. M. Frolich. 1993. Satellite radar interferometry for monitoring ice sheet motion: application to an Antarctic ice stream. Science, 262(5139), 1525-1530.

Gustavson, T. C. and J. C. Boothroyd. 1987. A depositional model for outwash, sediment sources, and hydrologic characteristics, Malaspina Glacier, Alaska: a modern analog of the southeastern margin of the Laurentide ice sheet. Geol. Soc. Am. Bull., 99(2), 187-200.

Jaeger, J. and 8 others. 2001. Orogenic and glacial research in pristine southern Alaska. Eos, 82(19), 213, 216.

Joughin, I., R. Kwok and M. Fahnestock. 1996. Estimation of ice-sheet motion using satellite radar interferometry: method and error analysis with application to Humboldt Glacier, Greenland. F. Glaciol., 42(142), 564-575.

Joughin, I. R., R. Kwok and M. A. Fahnestock. 1998. Interferometric estimation of three-dimensional ice-flow using ascending and descending passes. IEEE Trans. Geosci. Remote Sensing, GE-36(1), 25-37.

Kwok, R. and M. A. Fahnestock. 1996. Ice sheet motion and topography from radar interferometry. IEEE Trans. Geosci. Remote Sensing, GE-34(1), 189-200.

MacGregor, K. R., R. S. Anderson, S. P. Anderson and E. D. Waddington. 2000. Numerical simulations of glacial-valleylongitudinal profile evolution. Geology, 28(11), 1031-1034.

Meigs, A. and J. Sauber. 2000. Southern Alaska as an example of the longterm consequences of mountain building under the influence of glaciers. Quat. Sci. Rev., 19(14-15), 1543-1562.

Merrand, Y. and B. Hallet. 2000. Glacial landscapes evolution in sub-polar regions: an integrated field and theoretical study to model the evolution of the Chugach-St. Elias mountains, southern Alaska. [Abstract.] Eos, 81 (48), Fall Meeting Supplement, F1072.

Molnia, B. F. and J. E. Jones. 1989. View through the ice: are unusual airborne radar backscatter features from the surface of the Malaspina Glacier, Alaska, expressions of subglacial morphology? Eos, 70(28), 701, 710.

Page, R. A. 1969. Late Cenozoic movement on the Fairweather fault in southeast Alaska. Geol. Soc. Am. Bull., 80(9), 1873-1878.

Plafker, G. 1987. Regional geology and petroleum potential of the northern Gulf of Alaska continental margin. In Scholl, D. W., A. Grantz and J. G. Vedder, eds. Geology and resource potential of the continental margin of western North America and adjacent ocean basins. Houston, TX, Circum-Pacific Council for Energy and Mineral Resources, 229-268. (Earth Science Series 6.)

Plafker, G., J. C. Moore and G. R. Winkler. 1994. Geology of the southern Alaska margin. In Plafker, G. and H. C. Berg, eds. Quaternary geology of Alaska. Boulder, CO, Geological Society of America, 389-449. (The Geology of North America G-1.)

Rignot, E., R. Forster and B. Isacks. 1996. Interferometric radar observations of Glaciar San Rafael, Chile. F. Glaciol., 42(141), 279-291. (Erratum: 42(142), p. 591.)

Sauber, J., S. McClusky and R. King. 1997. Relation of ongoing deformation rates to subduction zone processes in southern Alaska. Geophys. Res. Lett., 24(22), 2853-2856.

Sauber, J., G. Plafker, B. F. Molnia and M. A. Bryant. 2000. Crustal deformation associated with glacial fluctuations in the eastern Chugach Mountains, Alaska. 7. Geophys. Res., 105(B4), 8055-8077.

Savage, J. C. and M. Lisowski. 1986. Strain accumulation in the Yakataga seismic gap, southern Alaska. J. Geophys. Res., 91 (9), 9493-9506.

Sharp, R. P. 1958. Malaspina Glacier, Alaska. Geol. Soc. Am. Bull., 69(2), 617-646.

Tarr, R. S. and L. Martin. 1912. The earthquakes at Yakutat Bay, Alaska, in September, 1899. U.S. Geol. Surv. Prof. Pap. 69.

Ulaby, F. T., R. K. Moore and A. K. Fung. 1982. Microwave remote sensing, active and passive. Vol. 2. Radar remote sensing and surface scattering and emission theory. Reading, MA, Addison-Wesley Publishing Co.

Zebker, H. A., P. Rosen, S. Hensley and P. J. Mouginis-Mark. 1996. Analysis of active lava flows on Kilauea volcano, Hawaii, using SIR-C radar correlation measurements. Geology, 24(6), 495-498. 